\title{
PHILOLOGY
}

\section{LITERARY EXPRESSION OF HUMAN AND MYSTICAL PERFECTION IN SOHRAB SEPEHRI'S POETRY}

\author{
Shoaliyeva Nargiza, International Islamic Academy of Uzbekistan, PhD, Senior Lecturer, Department \\ of Classical Literature and Origins, Tashkent, Uzbekistan
}

DOI: https://doi.org/10.31435/rsglobal_ijitss/31102019/6756

\begin{abstract}
ARTICLE INFO
Received 27 August 2019

Accepted 11 October 2019

Published 31 October 2019

\section{KEYWORDS}

Suhrab Sipehri, address, poem, symbol, mystic, love, eternity, classics, literature.

ABSTRACT

In the poem "Address", which was included in the collection "Green Volume" by S.Sepehri, in his own way he interprets the seven stages of asceticism - the "seven valleys", which are given in the dastan of Sheikh Fariduddin Attar "Mantik ut-tyr" ("Journey of Logic"). The article provides a comparative analysis of the spiritual stages of the poet's poetry - talab (need), ishq (love), marifat (enlightenment), isthiqno (denial), tavhid (unity), zairat (shock), fair (poverty) faqr fano (eternity). The path of Sufi perfection in the poem "Adress" is interpreted by the poet as a search for a "friend's house." In "The Journey of Logic," the path through the seven valleys ends in the valley of "poverty and eternity." Unlike Attar, Sepehri's path to perfection does not end at the "eternity" stage. It develops cyclically. Each time, without reaching the end, the path to the truth begins anew in a new form.
\end{abstract}

Citation: Shoaliyeva Nargiza. (2019) Literary Expression of Human and Mystical Perfection in Sohrab Sepehri's Poetry. International Journal of Innovative Technologies in Social Science. 7(19). doi: 10.31435/rsglobal_ijitss/31102019/6756

Copyright: (C) 2019 Shoaliyeva Nargiza. This is an open-access article distributed under the terms of the Creative Commons Attribution License (CC BY). The use, distribution or reproduction in other forums is permitted, provided the original author(s) or licensor are credited and that the original publication in this journal is cited, in accordance with accepted academic practice. No use, distribution or reproduction is permitted which does not comply with these terms.

Sohrab Sepehri's repeated appeal to mystical topics in modern Iranian poetry, which was developed on the basis of trends, being remote from traditional classical forms and topics once again proved that these topics are everlasting and capable to march along with the epoch's poetry. Sohrab Sepehri managed to repeatedly restore mystical topics and issues in 'the new poem' manner. The poet could present mystical topics and dogmatic issues not on the basis of the traditional principles and expressive ways, intrinsic to works by Jalaliddin Rumi, Sa'di Sherazi, Farididdin Attar, Hadez Sherazi, Abdurahman Jami, Alisher Navai and Mirza Bedil, but he could brilliantly cope with it through "his own newly-formed decent and ingenuous sincerity and mystic world viewpoint" (1).

Shams Langrudi appreciates Sohrab Sepehri's appeal to mystic topics as the poet's creative principle and reflectively rapid progress.

According to the scholar, with his collection book, titled "Downpours of the Sun" the poet announced strongly that he had entered the Oriental mystic world. The main point is that with this collection the poet had managed to get out of the influential circle, intrinsic to Nima Yushij's reflection principle. Having disagreed with Nima he heartily believes in the fact that "mankind's salvation path should not be in outwards, but it must be inwards." (2)

Sohrab Sepehri's works were devoted to mystic topics starting from his collection "Downpours of the Sun" up to "We are nobody except a glance".

Particularly, one can evaluate his collection of poems entitled 'Green volume' as the most beautiful mystic verses in the Iranian literature. The collection was warmly welcomed by researchers of the contemporary Iranian poetry. 
Having expressed their viewpoints and attitudes in literary books and articles on this collection many poets attempted to evaluate his works on their own (including Riza Barahani, Abdulali Dastghayb, Shams Langrudi). A great researcher Riza Barahani severely criticized not religion and mystic topics, presented in "Green volume", and Sohrab Sepehri's daily life, social and political events and social changes in the environments, but he slated Sepehri's poetic attention, dealt with religion and spiritual world, human internal world and internal survivals issues. (3) Having supported Riza Barahani's ideas a researcher of the literary process "the new poem" in Iran, Nuri Alo also attempted to involve the poet in social reality again, saying that in "Green Volume" Sohrab Sepehri went towards the way, which was led by Forugh Farruhzad in his late years of his short life.

According to the scholar's idea, the real natural difference between both aforementioned great poets' poetic ideas lies in the fact that social and vitally important elements attracted and encouraged Farruhzad's poetry. In reality Sohrab Sepehri didn't pay attention to these elements, and his verses were far from the daily life and "this way I will reach eternity", he thought so and had such unrealizable dream. (4) Since 1970-ies Sohrab Sepehri's mystic poems have been in the focus of the Iranian literary society. His new manner of thinking, particularly his mystic verses attracted the attention of not only specialists in the study of literature and critics, but also arts critics, politicians and the broad masses of population. Dariyush Ashuri emphasized very correctly that first of all Sohrab Sepehri is a perspicacious poet. However, this does not mean that he ruminated and created within the limits of traditional mystic outlooks, intrinsic to his country, and within the framework of previous thinkers. Because, spiritual selfless ascetic life in Sohrab Sepehri's works belonged not only to Sepehri's professional irfan, but it also penetrated into the bounds of Irfan teaching and broadened it, and enriched it with Indian and Japanese philosophic meditation. As a result, it was the combination of the most beautiful pieces of the whole Oriental irfan. (5) One cannot reject the issue that Buddha teaching, Japanese philosophy and Indian mystic contemplation made an impact on Sohrab Sepehri's world outlook. The aforementioned topic requires to be studied independently. For many years Sohrab Sepehri had traveled many countries of Europe and Asia. Having lived in Paris. London, Rome, Tokyo and Indian cities he learned religious and mystic teachings of different peoples.

As a result, foreign visits were the reason for the formation of his new world viewpoint, and his perceiving the life with a new reflection. While analyzing further literary processes after Nima Yushij in his research, titled "Diversities of innovatory in contemporary Iranian literature" Kavus Hasanli mentions Sohrab Sepehri's creation as a particular process: "Poets, like Sohrab Sepehri paid attention to the Universe-related issues and managed to demonstrate an individual outlook and viewpoint". (6) Through "the individual viewpoint" Sohrab Sepehri proved "to create particular mystic verses" in the modern Iranian poetry.

The poet's specific consideration is focused on his all mystic verses.

Having broken the old frame of traditional poetic symbols in Persian poetry Sepehri started his relation to people, life and the Universe, his personal outlook with creating new poetic symbols and symbols system. Hundreds of traditional symbols, like "lover", "sweetheart", "eye", "lip", "lock", "hair", "birthmark", "letter", "Majnun", "Layli”, "Farhad", "Shirin", "Besutun”, "adze”, "mountain”, "Sarv", "candle", "moth", "flower", "nightingale", "Wine”, "Jug”, "Cup", “Toast-master", "freeliver", "confessor", "traveler", "Khezr" (the Prophet Elias), "policeman", "monastery", "tavern", "a tavern-keeper", "an apprentice tavern-keeper" and others frequently appear almost in every line of Persian classic poets. Even some representatives of the Iranian poetry of the $20^{\text {th }}$ century, including prominent poets, like Bahar, Muhammad Husayn, Shahriar, Parvin Ettisami and Siymin Behbahani also appealed to aforementioned topics. Similar numerous traditional symbols exposed a new symbolic meaning in Sohrab Sepehri's poems

Particularly, "a mountain" poetic symbol in Sepehri's poems expresses not the mountain where from Farhad digged a canal or "Sinay" ("Turi Sino") "mountain" (7), depicted in religious literature, but they express "the loftiness of mankind spirituality" (8). Sepehri's imagination and fancy world is the world of permanent movement. He did not like stagnation and limitation. Probably, because of this reason the symbol of "Mountain" in the poet's some verses expresses the symbolic space - "a castle", but some of his poems express "natural mountain". While adding untraditional meanings to traditional poetic symbols Sohrab Sepehri created new poetic symbols, like "tulips", "night", "hurricane", "wave", "window", "stone", "glance", "forest", "water-lily", "leaf', "grief", "dream", "bird", "brightness", "darkness", "apple", "death", "fear", "upwards", "downwards", "smoke", "wind", "humming". With this he managed to enrich not only Irfan poetry, but also the new modern Persian poetic language, and could open its new horizons. In his mystic verses in the collections of "Downpour of Sunshine", "Sorrow's East", "Water's Foot Voice", "The Wayfarer" and "Green Volume" Sohrab Sepehri created his own literary interpretation in the mystic 
philosophy. Especially, the "wahdat ul-wujud" (the unity of creation) theory, tawhid ("doctrine of Oneness of God)", "perfect man" issue, the "tajalli" theory (A term used in Islam to describe the concept that the truth of the names and qualities of God is reflected in the world but does not enter into the world or is affected by it. The analogy is a mirror or shiny surface as light does not enter the mirror), the stages of enlightenment and truth, obtained new meanings and content in Sohrab Sepehri's interpretation. Some poems in Sohrab Sepehri's collection "Downpours of the Sun", including ("Prayer") and ("Come nearer") were filled with "wahdat ul wujud" philosophy. The poem "Prayer" ends with depicting the existence of mankind's spirit and absolute spirit in the coordinated space ("gold valley") and the separation of mankind's spirit from absolute spirit in the epoch ("fairy-tale), that is to say in boundless space (9).

We passed over radiance,

Completed the golden field,

Picked up a fairy-tale and threw droopingly...

.... Our silence mixed

And we became "We".

Our solitude stretched to the Golden field.

The Sun was afraid of us.

We found and smiled.

We hid, and burned...

We were parted in the sky:

I landed and became a servant,

You faced to the sky and became the God. (10)

Symbolic meanings of this poem resemble the story "Reed-pipe" (11) in Jalaliddin Rumi's work "Masnaviye ma'navi"

The reed-pipe was reed until it was cut.

It was happy being reed.

However, it was cut and made a reed-pipe from it.

As a result it lost its main thing - motherland.

Therefore, its melody was not simple melody, but it was "complaint from parting.

By the $20^{\text {th }}$ century the mystic poetry that ruled the Persian poetry for thousand years seemed to finish its task. From this point of view Sohrab Sepehri's entering the literary scene with mystic verses towards the path of "new poem" was unexpected, surprising event for Iranian literary society. Sohrab Sepehri's major success in this context was not limited with the changing of the form of verses or the enriching of mystic topics with Indian and Japanese philosophic teachings, but within the framework of mystic poetry he created new poetic symbols and new meaning and content system. In particular, the poem "Place" in the collection "Green Volume" by Sohrab Sepehri expressed seven stages - "the seventh valley", mentioned in the poem "Mantiq ut tayr" by Shaykh Fariddin Attar. While comparing and analysing valleys - moral and spiritual selfless ascetic life, depicted in "Mantiq ut tayr" by Shaykh Fariddin Attar with "signs", available along the so-called "To - find - the - friend's - house" way in the poem "The address" by Sohrab Sepehri, one can see a particular panorama filled with a particular poetic reflection.

Demand -In Article 29 of "Mantiq ut-tayr" a bird, led by Hoopoe, set for seeking for Seemorgh asks:

This path is full of difficulties and dangers

How long is it, tell me, friend? (12)

Hoopoe replied to the bird's query as follows:

It said: on the way you come across with seven valleys

A palace of light comes after seven valleys.

A traveler, going along this road will not return

Even if he returns does not tell how many farsangs is the road. (13)

In Sohrab Sepehri's poem the symbols of "a horseman" and "a traveler" were described instead of travelling birds and The Hoopoe correspondingly. The horseman asks the wayfarer how to get to his friend's "Address".

"Where is the friend's address?»

The horseman asked at dawn.

The sky hardened in a trice. (14)

What "the horseman" - "the bird" asked "the traveler" - "The Hoopoe" was not a simple question. This was such a question that the sky could stop the movement of the spiritual universe 
instantly. Because this question was directly connected with "the Friend" - "Seemorgh" (a fabulous, monstrous bird, corresponding nearly to the griffin), that is to say "Truth" (Creator)'s heavenly court.

By showing white poplar tree with his index finger

The traveler said. (15)

Here a tree "white poplar" was used as a poetic symbol of requirement rank. Sufis' term "requirement" means seeking for "demand" (desirable one, goal, aim). Actually, "desirable" is in the existence of the one, who is seeking for it. He should seek for it in his reality, otherwise he fails to find it. (16) The height of "the white poplar" is a hint to "the demand's" goal that cannot be reached, and its growing as straight and directly well-proportioned like cypress means that the direction of "the demand" is correct. The white color of the tree shows that the heart and intention should be transparent in "the demand" rank. However, in the middle of the poem the poet creates the second poetic symbol of "the demand". This poetic symbol is "a road between two gardens". "Kuchabogh" in Uzbek means "avenue", "open-air merrymaking". Precisely, "kuchabogh" is a green garden between streets. The tree "white poplar" also grew in this garden, but it was in the end of the avenue.

"Before reaching the tree,

There is a garden alley that is greener than God's sleep

And in it, love is as blue as the feathers of honesty. (17)

The poet mentions two qualities of "the avenue" - "demand" rank: greenness and love. Greenness is the symbol of adolescence, youth, innocence and the season of spring. Both "adolescence" and "spring" is the beginning of the status. From this point of view one can surely call "kuchabogh", that is to say "the avenue" is the poetic symbol of "the demand". (18) Thus, in the abovementioned quatrain the poet drew the picture of this valley with his notion through demandrelated symbols and descriptions. Mutually spiritual well-proportionness (the art of adequacy) (tree white poplar - avenue - green - greenness, love - tree; loyalty - bird, bird - wing; wing - volume) serves for the poet to rather clearly express his aim.

Then a valley of love opens a page

Those who reach it will be under the fire (19)

Love is the second (condition) valley in "Mantiq ut-tayr" by Fariddun Attar.

In his poem, titled "The address" Sohrab Sepehri created the mystic ideal - the new poetic symbol of "love" - the second sign along the way toward finding "The friend's house: this was expressed by "maturity" (perfection).

You will have to go along the street leading to perfection. (20)

There are very many poetic symbols of the term of "love" in Persian poetry, especially in Persian mystic poetry: wine, state, benefit, legend, flower garden, fire, chemistry.

However, Sohrab Sepehri called "love" as "adulthood" or "maturity".

In other words, the poet mentions "adulthood" as the metaphor of "love".

Sohrab Sepehri spent his whole life with the intention of "reaching the eternity" and he depicted this pain in his verses. This pain was the result of love, therefore only love could be balm and comfort him.

In other words, "love" itself was "the piece of evidence", which "encouraged the poet and led him to eternity and endlessness. (21) Because this concept encompasses everything: beauty, courtliness, purity, cleanness, good deed, happiness, power, courage, steadfastness, devotedness, loyalty, generosity, munificence, kindness and consequence.

Attar called "love" as "fire" in "Mantiq ut tayr" ("The love valley"). In his opinion, those who are not afraid of the fire can become a lover. A man, who gives up his existence and all his property, can successfully pass over the valley. (22) In the opinion of Mavlana Jalaliddin Rumi "love" is everything. Love is a force that can move the Universe and it is a remedy for all illnesses and problems.

Hey, take care, love is our amazing trade,

Hey our wise skilled healer!

Hey rescuer of our pride and dignity

Hey our Plato and Galinius!

With the help of Love one's body can travel the world

See how he is nimble to pass over mountains

Love is healing to Tur mountain, lovers

Tur is high and joyful, Moses is a guide... (23)

Thus, the notion of "love" is a concept that has been much used, expressed and interpreted. However, the word "love" was a word that was very rarely used in Sohrab Sepehri's works. (24) Without using this word Sepehri speaks about "love" (25). 
One day I will come

And will bring greetings.

The whole poem, called "Greetings in passing" (26) was filled with the spirit of love.

The poem was the brilliant example of Sepehri's love. A lover that had reached "the love" position (or according to Attar "the valley") despite their condition, whether it is beautiful or awful, good or bad, but all the same loves the nature and every creature of the Universe, every object and every situation.

They don't spare anything, and present everything to them, all good and benevolent deeds. They reconcile hostile creation and as a result lead them towards the path of "love". The aforementioned poem contains one word "love" and one word "to love". However, the spirituality, feeling and heart torments and its strivings, based on the content of the poem prove that just very heart emotion, its aspiration result in his hard labour. Precisely, "love" can mobilize mankind, and just "love" urges mankind to live, and precisely "love" can be criterion of his perfection. Afterwards Sohrab Sepehri analyzed more deeply the notion of "love" in his poem "Wayfarer".

And Love, only Love

Acquaints you with the warmness of apple.

And Love, only Love

Led me through the life's sorrows and breadth.

It gave me an opportunity to be a bird...

And Love

Means traveling to "objects' bright private place.

And Love,

Is an echo of distances. (27)

A frequently-used word "apple" in Sohrab Sepehri's poems is also a literary image.

Sohrab Sepehri's "apple" is "adulthood" and "maturity" and at the same time is a poetic image of "spiritual love".

The human might have an opportunity to feel high temperature of maturity through love, have access to "sorrowful breadths of life", and "to fly as a free bird".

Because, love means "to travel" to Universe objects that is to say to their "bright private place". Actually, love is a tone of voice of breakage between mankind, all distances and creature. People in both ends find each other with the help of an echo of the very distances and they strive to reach each other. Every line in the small passage of this poem contains a poetic symbol. Particularly, "the bird" was presented as a poetic symbol of a traveler of selfless ascetic life - "devotee" "Birds" in the works "Mantiq ut tayr" by Attar and "Lisan ut tayr" by Alisher Navai are also the symbols of wayfarers). Consequently, "objects' bright private place" are the symbols of "the real essence" (substance), and "distances" are the poetic images of separation between mankind and the God. Enlightenment - Sohrab Sepehri described the third sign along the way of "Friend's house" as "the eternal fountain of the Earth legends". While keeping on showing the way to the horseman, the wayfarer told the latter that after passing "adulthood" (maturity) street he is to turn towards "the flower of loneliness" and before reaching two steps prior to "the flower" he should stop at the footsteps of "the eternal fountain of the Earth legends".

Then turning to the flower of loneliness

You will reach the eternal fountain and myths. (28)

The purpose of "the Earth legends" is "long-standing truth". "Long-standing truth" is a quality, belonging to the God, that is to say the Creator. Thus, the poet created poetic image of "the long-standing truth" through the meaning of "the Earth legends". Differing from the classical poetry a new poetic image, created by the poet takes shape and keeps on improving and as a result the second poetic image will emerge. "The eternal fountain of the Earth myths". This complex poetic image, formed from the two literary symbols expresses the whole single symbolic meaning. "A perpetual spring of the starting mysteries", "the gushing-out eternal spring" is a path to be used for lighting up the ray candle in man's heart. Everything will be clear if "the signs" (stages) in Sepehri's poem, being subjected to analyses and explained by "the wayfarer" is compared with "the valleys" in "Mantiq ut tayr" by Attar.

Because Attar called the next (third) valley as "Enlightenment":

Then there will come into view

a great, eternal valley of enlightenment. (29)

Thus, Sohrab Sepehri fundamentally interpreted "The eternal fountain of the Earth legends" as "Enlightenment". Because "Enlightenment", that is to say the gift of cognizing the Universe and the Allah is really "perpetual spring", "eternal fountain". Actually, "according to Sufis cognizing the 
Allah is real enlightenment" (30). Likewise, Attar says that "a devotee, reached the enlightenment level will see only the Allah's face in the whole Universe":

Anything he sees, hee sees the God

He sees the God in every corner. (31)

A tasawwuf source, a hadith of the Prophet Mohammad says:

That is to say: "The one, who acknowledges the vital principle, acknowledges his God." (32)

This innermost meaning is mostly interpreted that "He, who acknowledges himself cognized the God, too. So, Sohrab Sepehri's viewpoints on "the enlightenment" stage and "the cognition of the Creator" were formed on the basis of such a formula.

Because he also tries to commence to find "himself" by cognizing wujud-e mutlaq [The Absolute Existence]. The poet's collection "Water's Foot Voice" poem depicts its lyric hero's trip to internal world, that is to say a journey to "himself". The hero makes a trip to "himself" and understands that he is an inseparable part of the universe that encircles him and makes another trip.

I went as to the party thrown by the world

I went to the field of sorrow

To the garden of mysticism

I went to the illuminated veranda of knowledge

I mounted the stairs of religion. (33)

A man, who is promoted from "his internal" trip to irfan (enlightenment) stage, reaches the radiant terrace of knowledge, arrives in vast breadth, coming out from religious and sect circle. Then he was able to acknowledge the essence of surrounding objects and events.

I saw many things on earth

I saw a child who sniffed the moon

I saw a gateless cage in which light was fluttering a flight of stairs

that love was mounted to the roof of heaven

I saw a woman pounding light in a mortar

At noon there was bread, vegetables,

distance of gillyflower in their tables,

and a hot bowl of affection...

I saw a beggar who hardly begged for the song of the swallow

And a street cleaner who was praying by the skin of a melon

I saw lambs that were eating kites

I saw an ass that understood the alfalfa

In the pasturage of advice I saw a well-fed cow...

During the process of selfless ascetic life the poet saw "the book, whose words were composed from crystal", "a spring seasonal paper", "a mosque in a far distance from water", "a hopeless faqeh [theologian], unable to find replies to his queries", "an essay-loaded mule", "a camel, loaded with an empty admonition basket", "Sufi, shipping thousands of "yo, hu", "radiant-carrying train", "staircases, leading to ... aimed at realizing the essence of objects and events During the trip the stage of cognizing, that is to say realizing, perceiving the movements, changes and process to be . in this stage the lyric hero realized that:

The seed's trip to flower.

Bindweed's trip from one room to another.

The Moon's trip over the pond.

The Sorrow-flower's sprout from soil...

The seed's trip to flower.

The seed's trip to flower.

Having ascended "the mystic staircase" and by discovering the essence of the Universe and its objects the ascetic came to such a conclusion: Before cognizing the essence of the Truth it is necessary to understand the meaning and essence of the Universe and universal issues. However, but all the same the main point is that human being cannot cognize the Creator. While calling the "Cognizing the Creator" issue, a major topic of the Kalam and Suffism teaching as "The secret of Red Rose" Sohrab Sepehri advises not to "introduce" with this "secret", but "to float" in its "witchcraft", that is to say in its qualities - in the essence of the Universe facilities and events.

It is not our business to acquaint with the "mystery" of rose

Perhaps our business is

To float within the "magic" of the rose. 
Generosity - Sohrab Sepehri's "wayfarer" called the fourth sign along the path of "the friend's house" as "the eternal fountain of the Earth legends", that is to say he called it "a flower of loneliness".

According to the description of "the wayfarer" a flower of loneliness" was located in two yards distance from "the eternal fountain of the Earth legends":

Then facing to the flower of solitude,

You will reach to the world's eternal fountain, myths.

If we take into account the fact that the aforementioned example interprets "the eternal fountain" as a poetic character of "enlightenment", then "a flower of loneliness" turns out to be a poetic symbol of the following mystic stage - "generosity".

Apparently, there seems to be no harmonic feature between the expression of "a flower of loneliness" and the term of "generosity".

However, harmonic feature between them appears in the coordination of lexical and metaphorical meanings: "loneliness", that is to say "solitude" points out the oneness of the God, and "the flower" in the singular form once again proves the oneness of the God. The word "generosity" means that "the God is free from wanting something from his servants", and He doesn't need anything. The God's freedom from want is displayed in his such qualities, like "oneness", "eternity" and "ability". While explaining the term "generosity" in relation to ascetics" spiritual status, it results in that the God is not in need of others and servants are in need before the God. Naturally, Sohrab Sepehri, who was closely acquainted with the creations of Sheikh Attar and Rumi, had a very good imagination on the notion of "generosity", that is to say "ascetic needs the God and does not need anything in relation to the people". This word, expressed with the name of the fourth valley of "Mantiq ut tayr" was used in the same meaning in Sohrab Sepehri's big work - in the poem "Water's Foot Voice".

I went up higher from post staircase.

I went to just round the corner of doubt street,

I went up to cool air of generosity,

And up to drenched night of love.

Attar called the fifth valley Tawhid. Sohrab Sepehri's wayfarer also showed "the horseman" the fifth sign:

And you will be obsessed with transparent fear.

In the sincere stream of the universe

You will hear a sound "khish-khish".

Regarding the word of "tawhid" dictionaries give the meaning "one" and interprets "oneness" [of God]. Religion considers "tawhid" as necessary unbreakable legislation and important persuaded need.

"Tawhid" is the the beginning of "cognition".

Sohrab Sepehri created the Allah's uniqueness, that is to say he originated a new poetic image of "the tawhid" notion. The poet called the new essence as "the Space's sincere flows". It is a complicated issue to find out to which extent the poetic image and "the tawhid notion" are interrelated meaningfully or logically. Because it is a poetically abstract imagination and fantasy product, which is intrinsic only to Sohrab Sepehri.

It is only known that the poet found a beautiful picture to his liking to express "tawhid" notion.

Anyone, who intellectually realizes the cosmic reality of the Universe, and the Galactic system's expansion he will also comprehends that how the space notion is wide and boundless. From this point of view it is also a hint to the fact that "the space's expansion is a reality", and at the same time only in the very wide scope one could see the uniqueness of material and spiritual content, created by the Almighty. In some verses Sepehri more clearly explained "the tawhid" notion.

For example, in his poem, titled "Until" he emphasizes that "the uniqueness casts shed on Time and Space". Sohrab Sepehri is a "tawhid" poet; he accepted, realized berhymed and made a great contribution to popularize "tawhid". As a religious, ethic, aesthetic, intellectual, sensational and mystic category "tawhid" occupied an authoritative place in the poet's poetic reflection, and it served to systemize to some extent the poet's balance between the universe, mankind and the Creator. It also served to create a modern interpretation of "uniqueness", "single uniqueness" and "mutual interrelationship" philosophy. Therefore, "tawhid" is one of the main topics in the poet's literary heritage and world outlook." The sixth valley in "Mantiq ut tayr is Hayrat [astonishment] valley. Attar says: "You will be enchained by pain and sorrow in this valley. Here each breath penetrates as a blade, and in every minute you will be remorseful ... The mystic was in deep sorrow and pain torments him in imagination. The wayfarer was puzzled how to reach the destination, and was lost in imagination. Along the path of 'Astonishment' he lost his way. He also lost his existence, the space, the Universe..." 
Sohrab Sepehri's "Wayfarer" calls the sixth sign on the way to "the friend's house" as a boy on a pine-tree."

You will see a child

Who has gone up the pine tree,

to grab a birdie from the nest of light.

There is close relation between "Astonishment" and "childhood" in meaning. Logically 'astonishment' is a typical sensation, intrinsic to "childhood". Because, childhood period is a world of astonishment and surprises. It is a period of seeing world objects with astonishing eyes and discovering things. Therefore, the poet chose "the boy on the high pine-tree" as a poetic image of "the astonishment" status.

In irfan, formed in the Islamic religion scope every issue, every moral stage are explained with alarming and emotional sensations, like "hardship", "pain and sorrow", "grief and sadness", "parting and separation" and etc. However, as for Sohrab Sepehri, who realizes mankind in the bosom of beauties, and loves the nature and its creation was difficult to express such words.

Therefore, in his mystic verses the poet decides to use optimistic words, word combinations and expressions and images. From this point of view Sohrab Sepehri interprets mystic "astonishment" by mixing natural and psychological "astonishment". According to Sepehri "astonishment" and "childhood" are the notions that have the joined meaning.

Through the notion of "childhood" he exposes the mystic meaning of "astonishment". Particularly, in his poem, titled "Beyond seas", presented in his collection "Green volume" the mystic appearance of the ideal city was described as follows:

There is a single city beyond the seas

It is the city, whose windows are open to the tajalli side.

Doves that have built nests to its roofs are looking at the people,

who are gushing out as fountains.

Each 10-year old child has in hands branches of enlightenment.

The city's population cast a glance to every ear (of grain)

As a nice dream, as if they are looking at a piece of radiance.

In the abovementioned poem extract "the city" that was open towards "tajalli" is the sign of deep loyalties to the Creator, "fountain-like gushing-out of the people" means the formation and demonstration of faith secret in their hearts, "dove" is the symbol of purity and kindness, as intrinsic to faith, "infant", that is to say "child" is the symbol of the human, who realized with "astonishment" the secret of the Creator, "enlightenment in hands" is the process of knowledge, belief and comprehension towards the path of reaching the Almighty, "ear" [of grain] - the reflection symbol of the Creator concerning to every creation of the Universe, "radiance" is the Creator's ray and "dream" is the destination of traveler, where to he rushes. During the process of "spiritually perceiving oneself" precisely through child image one concentrates his strong feeling in relation to belief and regard it with "astonishment" eye. "Astonishment" is interpreted as inseparable part and organic unity along the path of cognizing the Creator. Kavus Hasanli compared motives of childhood period in Sohrab Sepehri's poems with the same period in Forugh Farrukhzad's poems. With this comparison and during depicting Sepehri's childhood period he established contact between nature and life situation.

Therefore, in this respect he is very similar to Forugh Farrukhzad", he said.

However, the researcher did not concentrate to the facts that Sohrab Sepehri's childhood period motives were harmonized with simple life and environmental depiction of the nature, and at the same time it served as mystic poetic image.

Thus, "astonishment" category of mystic reflection in Sohrab Sepehri's poetry were reformed in a new content for the interpretation of mystic ideas and was glorified. In reality, poverty and nonexistence in Tasawwuf teaching are two separate and independent conceptions. Particularly, in his work, titled "Al-Luma" a very outstanding scholar, Abu Nasr Sarroj classified maqamat [positions] spiritual stages of tasawwuf tariqa (teaching). He dwelled on each matter and mentioned "poverty" as the fourth maqam [position] after "tavba" [repentance], "abstinence from sin" (chastity) and "asceticism" (abstemiousness).

Literary meaning of the word "poverty" is "need" and "insufficiency". According to Sufi's term it means "to be in need before the God and not to be in need before some other people. Thus, as a term "poverty" is very in meaning with the fourth valley - "Generosity" in the work "Mantiq ut-tayr". However, Attar joined "poverty" with "non-existence" and mentioned it as the last valley. When Attar reached this valley negative defects and dispositions, casting shed to the human vanished as "the Sun 
annihilated hundred thousands shadows. Literary meaning of "poverty" is "non-existence". According to Sufi's terminology "non-existence" means that the human consider that their servitude "does not exist" before the God, and they restrain from their wills and desires, and perceive the world and world objects "nothing" before the God. Sohrab Sepehri rests upon only the notion of "non-existence".

"The Wayfarer" explained "the horseman" the last sign in "the friend's house" as follows:

You will see a child

Who has gone up the pine tree,

to grab a birdie from the nest of light.

It is clear from this extract that here Sohrab Sepehri did not equalize the last sign - the last destination "non-existence" The poet's life-loving feeling prevailed. Sohrab Sepehri's torrid glance accustomed to see the things in beauties and see beauties in things. Therefore, he created absolutely new poetic content of the "non-existence" notion. "The nest of light" is the complex of "non-existence". "The nest of light" is the complex of "non-existence". In the style of relating to "non-existence" "the nest of light" is the last destination that concentrated divine power and life essence in itself. There are many izafet [Grammatical word: the addition of a noun to another noun or pronoun in the genitive case denoting possession, apposition, etc.] allegories in Sepehri's poems that are made with the word "light".

Particularly, in his collection "The Life of Dreams" in the poem "Gul-e koshi" ["Glazed tile"] the "rain's radiant" notion was applied. But it is impossible to say that all Sohrab Sepehri's

In general, the "non-existence" notion is rather appropriate notion to Sohrab Sepehri's spirituality and nature.

Most of his poems in the collection "East of sorrow" were filled with non-existence spiritualism. One can include to this type of poems "Hey", "Suspicion-seeker", "The passing spot", "To my rebellion", "Bodhi", "Until", "And I was broken, ran, fell". In his poem "Hey" the poet said "I am nothing", and in his poem "Suspicion-seeker" he said "I went, "He" came". In Sohrab Sepehri's poem "The passing spot" "non-existence", intrinsic to [Jalaliddin] Rumi was berhymed.

Neither you will remain, nor I will, open your eyes in tears

Death has come, open the door.

In some of his poems Sohrab Sepehri refused to talk in the language of images and symbols, and appealed to the traditional content of mystic terms.

In particular, the term "non-existence" was used in its literary and mystic meaning in his poem, titled "Rebellion".

I am a musical instrument, and confident to voice, don't be lazy,

Take the instrument and play. Play "Lo" [C] the tar, choose the path of non-existence.

Apparently, "Lo" is concordant with the first tone in printed music "C" ['do']. However, it is not only the first tone of the musical instrument of 'tar' [the typical Persian instrument of music, resembling more or less a guitar, and having usually six strings], but it is the last tone, too. There is no difference for the poet between commencement and termination. Because, both of them are "Lo", that is is to say it means "non-existence". In its turn "non-existence" means just "non-existence" again. Sometimes Sohrab Sepehri's "non-existence" outreaches the "non-existence" circle in tasawwuf teaching, and mixes the "nirvana" notion:

It was an instant, doors were open

Neither a leaf, nor a branch, nor non-existence garden were seen.

The birds' trip over seven valleys ends with the "poverty and non-existence" valley. However, Sepehri's "Wayfarer", that is to say his "The Hoopoe" gives somehow different instruction to the "horseman": "After seeing a boy, who was climbing up a pine-tree and taking a birdie from "The nest of light" you will ask him: Where is the friend's house"?

And you will ask him

"Where is the friend's house?"

Thus, differing from Attar Sohrab Sepehri's attempts to find "the friend's house" does not end with the "non-existence" stage. On the contrary, after reaching this stage traveling and wandering towards seeking for "the friend's house" - the Truth destination starts again. Because, the question "where is the friend's house?" has been posed. The process of realizing the content and essence of the universe, created by the Almighty continues as a circular form. In other words, traveling and wandering towards seeking for the Truth resumes again when this process is just about reaching the final stage. In addition to this, Sohrab Sepehri's rhetorical question "where is the friend's house?" was not directed only to the lyric hero of the poetic work, but it was also directed to a reader, who had already learned Sohrab Sepehri's creation and was asking himself a question about his own life style. 
That is to say, it is a hint to a reader that he is obliged himself to seek for and know "where is the friend's house?". Thus, the question "where is the friend's house?" is emphasized and directed to three persons. At the beginning the poet posed this question to himself. Later, the question was posed to the poem's hero. In the end a reader is compelled to find a solution of the question. Making up a conclusion, one can say that Sohrab Sepehri's creation became a basis to serve for the creation of new mystic poetic images. The poet gave new meaning to traditional mystic conceptions, reformed them in the new content. Likewise, he used to interpret mystic ideas under new cogitation. Probably, owing to this fact Sirus Shamiso said: "Sohrab Sepehri is a poet whom it is hard to comprehend". Due to the fact that he had deep mystic understanding, he made a conclusion that it was impossible to enter a creator's literary world". To understand the content of the poetic symbols, created by Sohrab Sepehri and more deeply scrutinizing require to conduct special research on the aforementioned issues.

\section{REFERENCES}

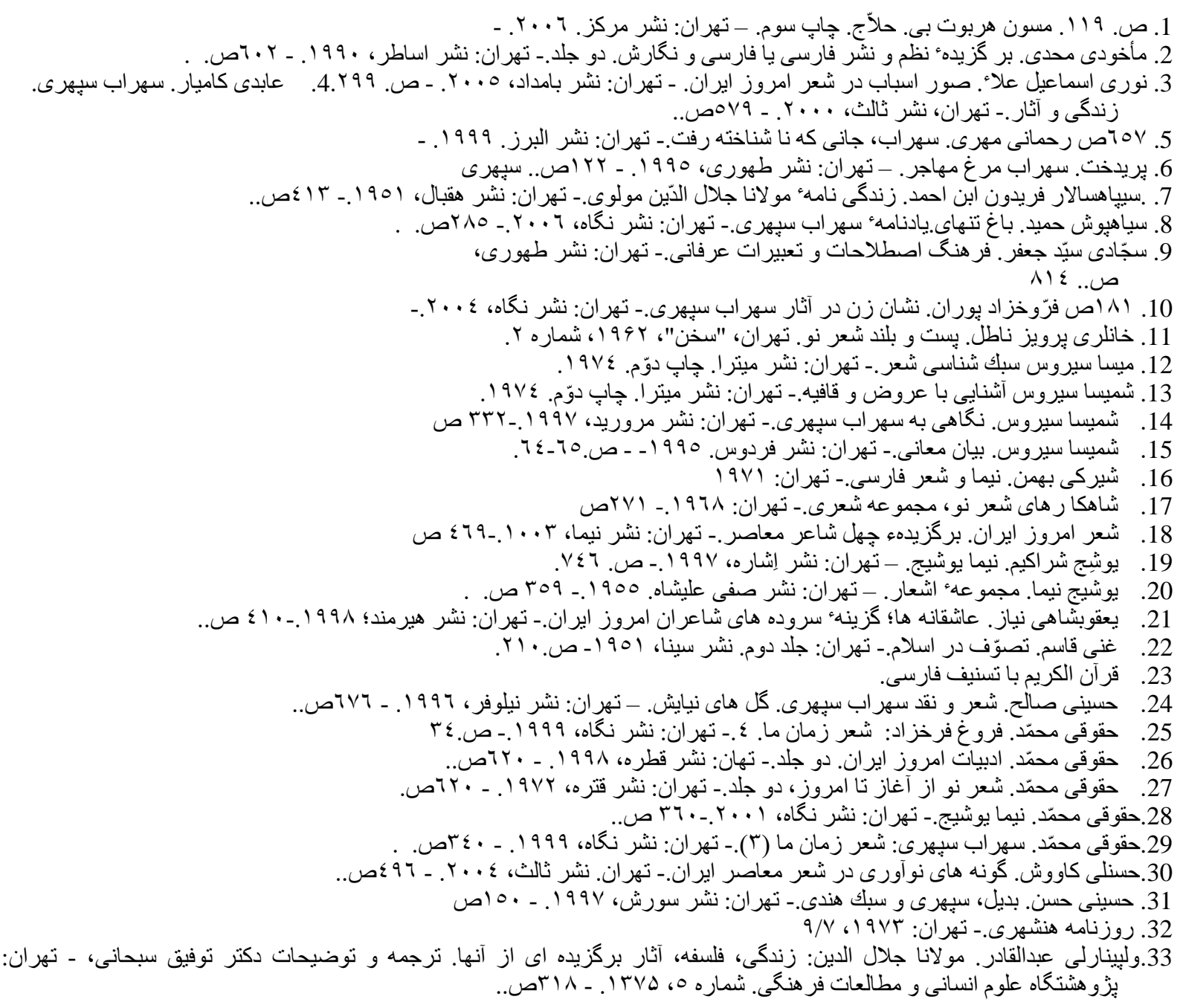

